Шило Ж. С., к.е.н., доцент (Національний університет водного господарства та природокористування, м. Рівне)

\title{
АНАЛІЗ ТА ОЦІНКА ПОКАЗНИКІВ БОРГОВОЇ БЕЗПЕКИ ДЕРЖАВИ В КОНТЕКСТІ УПРАВЛІННЯ ФІНАНСОВО-ЕКОНОМІЧНОЮ БЕЗПЕКОЮ
}

В науковому дослідженні проаналізовано рівень боргової безпеки держави. Автором розкрито теоретико-методологічні засади формування та оцінювання боргової безпеки, виділено основні їі загрози та небезпеки, систематизовано та проаналізовано їх значення для України. Проведено оцінку рівня боргової безпеки держави, запропоновано напрями покращення управління державним боргом та оптимізація боргової безпеки.

Ключові слова: боргова безпека; управління фінансово-економічною безпекою; індикатори стану боргової безпеки; державний та гарантований державою борг; середньозважена дохідність ОВДП.

Вступ. В умовах нестабільності економічних і політичних реалій у суспільстві, рівень боргової безпеки держави $€$ однією 3 найважливіших складових фінансово-економічної безпеки. Це своєрідний індикатор і критерій ефективної зовнішньо та внутрішньо економічної діяльності держави. Без досягнення достатнього рівня боргової безпеки держави, на сучасному етапі, неможливо вирішувати завдання економічного, фінансового та політичного іï розвитку на перспективу.

Сутність боргової політики України показує зростання внутрішньої і зовнішньої заборгованості держави, що може призвести до негативних наслідків в економічній та фінансовій сфері, а також нести загрозу національній безпеці держави.

Враховуючи вищевикладене, необхідність проведення дослідження і оцінки основних показників (індикаторів) боргової безпеки держави є вкрай актуальними на сьогодні.

Аналіз публікацій. Проблемами боргової безпеки, визначенням ii індикаторів та вдосконаленням методики оцінки їх рівня займалися такі вітчизняні вчені: Т. Боголіб, О. Василик, І. Запатріна, Л. Козарезенко, Г. Кучер, І. Лук'яненко, І. Луніна, В. Міщенко, В. Опарін, Г. П'ятаченко, В. Федосова, А. Чухно, С. Юрій та інші. Але, на наш погляд, незважаючи на всю важливість поставленого завдання оцінки стану боргової безпеки держави, відбувається нарощування 
боргового навантаження та зниження боргової стійкості, що потребує подальшого дослідження та удосконалення методології розрахунку інтегральних показників та підходів до оцінювання рівня боргової безпеки.

Мета статті. Метою написання наукової статті $€$ необхідність проведення теоретичного та методологічного дослідження етапів формування та оцінювання державної боргової безпеки, виділення певних загроз, систематизація та аналіз їх значень для України 3 позицій наближення їх до визначених оптимальних параметрів, розроблення певних чітких рекомендацій для вдосконалення окремих груп індикаторів боргової безпеки та їх критичних значень стосовно сучасних реалій.

Відповідно до поставленої мети, нами були окреслені наступні завдання: дослідити теоретико-методологічні засади рівня оцінки боргової безпеки держави; здійснити аналіз певної групи індикаторів, що характеризують боргову безпеку держави; виділити певні загрози і здійснити заходи для покращення боргової безпеки.

Основний розділ. В умовах трансформації економічних та політичних процесів, поняття боргової безпеки визначається як складова фінансово-економічної безпеки держави. Основним показником, що характеризує суть боргової безпеки $є$ показник державного боргу та його відношення до валового внутрішнього продукту у відсотках.

При розкритті сутності боргової безпеки, ми виділили, такі теоретичні підходи:

- Рівневий - боргова безпека розглядається як рівень перевищення заборгованості, що призводить до залучення нових позик.

- Елементний - боргова безпека розглядається як елемент системи вищого рівня [10].

- Функціональний - боргова безпека розглядається як здатність дотримання певного рівня заборгованості.

- Управлінський - боргова безпека розглядається в контексті управління державним боргом.

В сучасних фінансово-економічних умовах більшість держав світу використовує певні напрями фінансування у вигляді позик та кредитів, і наша держава не виключення. Протягом тривалого часу розмір державного боргу тільки збільшується, на це впливає нестабільний економічний та політичний розвиток, проведення військової операції на Сході, зниження мікро- та макроекономічних показників, що в свою чергу відображається на рівні їі боргової безпеки.

Узагальнивши наукові розробки окремих зарубіжних та 
вітчизняних науковців, нами було виділено фактори, які визначають ступінь боргової безпеки держави:

1. Рівень інституційного забезпечення системи управління державним боргом, зокрема ступінь інформаційного та нормативноправового забезпечення, що регламентує формування та управління державним боргом, стратегію та тактику боргової політики держави [2].

2. Показники, які визначають обсяг, динаміку і структуру державного боргу, а також терміни його погашення.

3. Проведення стабільної монетарної політики в державі, що впливає на стійкість валютного курсу та зміну облікової ставки НБУ.

4. Дотримання політичної та економічної рівноваги в державі. Державні економічні та політичні ризики потребують використання зовнішніх позик, що в свою чергу призводить до надання частини ВНП держави зовнішнім кредиторам.

5. Наявність необхідного боргового досвіду держави та кредитного рейтингу в світі. Незначний кредитний рейтинг держави свідчить про наявність певних економічних або політичних ризиків, що впливає на зміну поняття боргової безпеки.

Для проведення оцінки та аналізу боргової безпеки держави використовується система певних індикаторів, що показують обсяги боргового навантаження держави та показники ії боргової стабільності. Результати управління державним боргом залежать від використання певної систематизованої групи показників боргової безпеки України, так і зарубіжних держав.

Оцінку рівня боргової безпеки здійснюють з використанням різних показників-індикаторів: Світового банку, Міжнародного валютного фонду, Міністерства економічного розвитку України.

Так, Світовим банком розроблена система індикаторів боргової безпеки держави, яка включає наступні показники: відношення сукупного зовнішнього боргу до експорту товарів і послуг; відношення сукупного зовнішнього боргу до ВНП; відношення загальних платежів щодо обслуговування боргу до експорту товарів і послуг; відношення сукупних відсоткових платежів до експорту товарів і послуг; відношення міжнародних резервів до сукупного зовнішнього боргу; відношення короткострокового боргу до сукупного зовнішнього боргу; відношення боргу міжнародним організаціям до сукупного зовнішнього боргу; відношення міжнародних резервів до імпорту товарів і послуг.

За виділеними показниками-індикаторами можна проводити оцінку рівня боргового навантаження та аналізувати стан боргової безпеки певної країни, але не існує визначених «порогових» 
значень, перевищення яких було б загрозливим для держав 3 розвиненою та трансформаційною економікою.

Показники-індикатори для аналізу рівня боргової безпеки, які розроблені Міжнародним валютним фондом, за висновками фахівців, не показують зв'язок державного боргу 3 відтворювальними процесами в економіці і не впливають на фінансово-економічне зростання держави, тому їх застосування в окремих державах відбувається не в повній мірі.

Методику розрахунку рівня економічної безпеки України було затверджено Міністерством економіки у 2007 році. Пї подальше доопрацювання відбулося в 2013 році, тоді були вдосконалені саме індикатори боргової безпеки держави необхідні для визначення їі боргового рівня на перспективу.

Згідно даній методиці показник відношення обсягу державного та гарантованого державою боргу до ВВП має бути в межах 20-60; показник відношення обсягу зовнішнього боргу до ВВП в межах 4070; показник середньозваженої дохідності ОВДП на первинному ринку в межах 4-11; показник відношення обсягу офіційних міжнародних резервів до обсягу валового зовнішнього боргу в межах 20-50 [4].

Слід зазначити, що показники стану боргової безпеки держави, які використані у даній методиці розрахунків рівня економічної безпеки, $€$ не достатніми для проведення якісного фінансовоекономічного аналізу боргового навантаження держави в цілому.

В нашому дослідженні будемо проводити оцінку i аналіз показників боргової безпеки держави за допомогою вітчизняної методики та індикаторів, розроблених нашими науковцями.

Визначення та аналіз показників боргової безпеки України неможливо розглядати без показників державного і гарантованого державою боргу. Наведемо динаміку стану та структури державного і гарантованого боргу України за період 2015-2019 років в табл. 1.

Аналізуючи показники табл. 1, ми бачимо, що порівнюючи 2019 рік з попереднім роком загальна сума державного та гарантованого державою боргу зменшилась на 170,35 млрд грн. Враховуючи такі тенденції можливо відмітити певну позитивну динаміку. На це вплинуло, в першу чергу скорочення державного боргу у 2019 році на 0,06\% та гарантованого державою боргу на 0,24\%. Також відбулося зниження державного зовнішнього боргу в порівнянні з 2018 роком на 238 млрд грн, але незважаючи на оптимістичні прогнози, валовий зовнішній борг держави збільшився в 2019 році і досяг 199,95 млрд дол. За даними НБУ, зростання зовнішнього боргу відбулося переважно за рахунок збільшення зовнішніх зобов'язань приватного сектора економіки, що зросли на 
4,4 млрд доларів (до 69,7 млрд доларів, або 47,8\% від ВВП).

Таблиця 1

Динаміка державного та гарантованого державою боргу України за 2015-2019 роки, млрд грн

\begin{tabular}{|l|c|c|c|c|c|}
\hline \multicolumn{1}{|c|}{ Показники } & 2015 & 2016 & 2017 & 2018 & 2019 \\
\hline $\begin{array}{l}\text { Державний та } \\
\text { гарантований } \\
\text { державою борг }\end{array}$ & 1572,18 & 1992,81 & 2141,67 & 2168,63 & 1998,28 \\
\hline Державний борг & 1334,27 & 1650,83 & 1833,71 & 1860,50 & 1761,37 \\
\hline Внутрішній борг & 508,00 & 670,65 & 754,00 & 761,09 & 829,50 \\
\hline Зовнішній борг & 826,27 & 980,19 & 1079,71 & 1099,41 & 931,87 \\
\hline $\begin{array}{l}\text { Гарантований } \\
\text { державою борг }\end{array}$ & 237,91 & 278,98 & 307,96 & 308,13 & 236,91 \\
\hline Внутрішній борг & 21,46 & 19,08 & 13,28 & 10,32 & 9,56 \\
\hline Зовнішній борг & 216,45 & 259,89 & 294,68 & 297,81 & 277,35 \\
\hline $\begin{array}{l}\text { Державний } \\
\text { зовнішній борг }\end{array}$ & 1042,72 & 1240,08 & 1374,99 & 1397,22 & 1159,22 \\
\hline $\begin{array}{l}\text { Валовий зовнішній } \\
\text { борг, млрд. дол. }\end{array}$ & 118,73 & 113,52 & 116,58 & 114,71 & 119,95 \\
\hline
\end{tabular}

Джерело: складено автором за [8; 9]

На наш погляд, така тенденція потребує постійного зростання витрат на обслуговування державного боргу, що показує неспроможність нашої держави забезпечити свій економічний розвиток за рахунок власних внутрішніх джерел та державних надходжень.

Враховуючи попередні розрахунки, ми визначили інтегральний показник боргової безпеки України за 2015-2019 роки (табл. 2).

Таблиця 2

Інтегральний показник боргової безпеки України за

2015-2019 роки

\begin{tabular}{|l|c|c|c|c|c|}
\hline \multicolumn{1}{|c|}{ Показники } & \multicolumn{5}{|c|}{ Роки } \\
\cline { 2 - 6 } & 2015 & 2016 & 2017 & 2018 & 2019 \\
\hline $\begin{array}{l}\text { Відношення обсягу державного } \\
\text { та гарантованого державою боргу } \\
\text { до ВВП,\% }\end{array}$ & 79,4 & 81,0 & 71,8 & 60,9 & 51,7 \\
\hline $\begin{array}{l}\text { Відношення обсягу зовнішнього } \\
\text { боргу до ВВП,\% }\end{array}$ & 48,0 & 48,9 & 46,1 & 39,3 & 30,1 \\
\hline $\begin{array}{l}\text { Середньозважена дохідність } \\
\text { ОВДП на первинному ринку,\% }\end{array}$ & 12,45 & 9,12 & 10,47 & 17,79 & 18,04 \\
\hline
\end{tabular}




\begin{tabular}{|l|c|c|c|c|c|}
\hline $\begin{array}{l}\text { Відношення обсягу офіційних } \\
\text { міжнародних резервів до обсягу } \\
\text { валового зовнішнього боргу,\% }\end{array}$ & 11,19 & 13,69 & 16,13 & 17,89 & 21,09 \\
\hline $\begin{array}{l}\text { Інтегральний показник боргової } \\
\text { безпеки }\end{array}$ & 0,293 & 0,412 & 0,320 & 0,397 & 0,285 \\
\hline
\end{tabular}

Джерело: складено автором за [8; 9]

Проаналізуємо показники наведеної таблиці.

Перший показник - це відношення обсягу державного та гарантованого державою боргу до ВВП у 2019 році має тенденцію до зниження і становить 51,7\%, що нижче критичного значення (60\%), це $\epsilon$ свідченням проблем в частині боргової безпеки держави.

Другий показник-індикатор, весь досліджуваний період мав критичні значення. При чому найбільш загрозливою була ситуація у 2018-2019 роках, коли він знизився до 30,1\%. Експерти МВФ визнали, що критичною сумою зовнішнього боргу для держав 3 низьким і середнім рівнем доходів $€ 49,7 \%$ від ВВП. Україна уже перетнула даний показник.

Третій показник-індикатор - середньозважена дохідність ОВДП на первинному ринку - має негативне значення, адже показники 3 2015 по 2019 рік перевищують критичне значення в середньому на $3,6 \%$. За аналізований період жоден 3 показників не мав оптимального значення, а перевищував поріг $11 \%$, що свідчить про критичну ситуацію, тому, що велика доходність по ОВДП збільшує вартість обслуговування державних боргів та створює додаткове навантаження на державний бюджет.

Четвертий показник характеризує як валовий зовнішній борг держави може бути профінансований за рахунок золотовалютних резервів. В цілому, аналізуючи ситуацію з 2015 по 2018 роки, спостерігається незначне зростання значення показників, але всі вони є критичні, тому потребують відповідних заходів для подолання такого рівня та наближення до оптимального. Тільки в 2019 році цей показник перетнув критичну межу (20\%) і склав $21,09 \%$.

На основі розрахованих нами значень за кожним індикатором боргової безпеки можна визначити загальний інтегральний показник боргової безпеки держави.

Застосування інтегральної оцінки рівня боргової безпеки відповідно до Методичних рекомендацій [4] здійснюється за допомогою певних вагових коефіцієнтів, за шкалою від 0 до 1 або у відсотках. Розрахований нами за такою методикою інтегральний показник рівня боргової безпеки України вказує на ї̈ критичний 224 
стан. Починаючи з 2016 року, Уряду вдалося дещо покращити рівень внутрішньої та зовнішньої заборгованості, але говорити про стабілізацію боргової безпеки в цілому ще зарано, оскільки вона знаходилася у 2019 році на критичному рівні та потребує негайних заходів щодо ії нарощування.

Проведене нами дослідження рівня боргової безпеки дає підстави стверджувати, що перелік показників ії стану, передбачений у вищезазначеній методиці, не $\epsilon$ достатнім для здійснення повного аналізу боргової безпеки держави.

Аналізуючи погляди вітчизняних та зарубіжних науковців на визначення показників, що дають оцінку рівню боргової безпеки, нами запропоновано доповнити їх перелік 3 урахуванням економічних особливостей нашої держави. Серед яких найбільш прийнятними вважаємо наступні: відношення обсягів платежів 3 обслуговування зовнішнього (внутрішнього) державного боргу до річного експорту товарів і послуг; відношення обсягів платежів 3 обслуговування зовнішнього (внутрішнього) державного боргу до доходів державного бюджету; відношення заборгованості уряду за державними цінними паперами до ВВП. Запропоновані показники оцінки рівня боргової безпеки держави допоможуть підвищити її платоспроможність, вчасно запобігати фінансовим кризам, та коригувати боргову політику держави, підвищувати їі дієвість для забезпечення стабільного фінансово-економічного розвитку.

Наукове дослідження, яке було проведене за період 2015-2019 pp. свідчить про незадовільний стан боргової безпеки та перевищення окремими індикаторами критичних значень, що $\epsilon$ ознакою кризових явищ в економіці держави.

Основними причинами появи таких негативних показників боргової безпеки, на нашу думку, є: покриття щорічного дефіциту державного бюджету та платіжного балансу, перевищення експорту над імпортом, високий ступінь залежності України від імпортованих енергоносіїв, відсутність чіткої державної стратегії щодо управління державним боргом, малоефективний контроль за цільовим призначенням і використанням запозичень.

3 метою оптимізації боргової безпеки держави, нами запропоновано здійснити низку заходів, які зможуть покращити систему управління державним боргом:

- вдосконалити нормативно-правову базу шляхом прийняття базового закону про зовнішній державний борг, що визначатиме основні пріоритети та напрямки боргової політики держави; 
- врегулювати порядок видатків державного бюджету, які необхідні для управління державним боргом та повноваження органів державної влади, які беруть участь у процесі, 3 обслуговування, погашення та управління державним боргом;

- використовувати наявні фінансові можливості держави для ефективної реалізації програм інституційно-інвестиційного розвитку, а не спрямовувати на статті споживчого їх розвитку;

- зменшити частку зовнішньої заборгованості в загальному обсязі боргу держави, оскільки зовнішні позики є цілеспрямованим вивезенням капіталу за їі межі;

- дотримуватись економічно обгрунтованого обсягу дефіциту державного бюджету та визначати основні напрями підвищення доходів бюджету, за рахунок власних інвестицій в економіку.

Висновки. Проведений нами аналіз та оцінка показників рівня боргової безпеки показали наявність певних недоліків, як в методиці їх застосування, так і в якісній їх характеристиці.

На наш погляд, вирішення існуючих проблем боргової безпеки неможливе лише інструментами боргової політики. На сам перед, в державі, слід провести комплекс заходів, направлених на стримування інфляційних процесів, стабілізацію національної валюти, оптимізацію структури бюджетних видатків, включаючи введення певних грошово-кредитних обмежень, здійснити стимулювання внутрішнього державного ринку та вітчизняних підприємств за допомогою податкових інструментів.

Проводити оцінку впливу факторів боргового навантаження на економіку з метою уникнення боргової кризи в державі, доцільно за такими напрямками:

- спрямовувати, залучені зовнішні запозичення на реалізацію програм інвестиційного розвитку держави, які забезпечать в майбутньому їі економічне зростання;

- оптимізувати структуру державного боргу з врахуванням змін у фінансово-економічному середовищі та майбутні ризики на валютному ринку;

- застосувати механізм та методику проведення моніторингу боргової безпеки держави, для оптимізації факторів, які впливають на зниження ризиків, при збільшенні боргового навантаження держави;

- розробити та законодавчо затвердити перспективну боргову державну стратегію в умовах трансформації економіки;

- збалансувати дохідність за зовнішніми і внутрішніми державними позиками; 
- скоротити витрати державного бюджету, які призводять до зростання бюджетного дефіциту, що в цілому впливає на зростання боргової залежності держави.

1. Про основи національної безпеки України : Закон України від 19.06.2003 № 964IV (зі змінами і доповненнями). URL: http://zakon4.rada.gov.ua/ (дата звернення: 15.02.2020). 2. Програма управління державним боргом на 2017 рік : наказ МФУ від 31.01.17 № 19. URL: http://www.minfin.gov.ua (дата звернення: 15.02.2020). 3. Про затвердження Середньострокової стратегії управління державним боргом на 2017-2019 роки : Постанова Кабінету Міністрів України від 1 грудня 2017 р. № 905. URL: http://zakon5.rada.gov.ua/laws/ (дата звернення: 15.02.2020). 4. Про затвердження Методики розрахунку рівня економічної безпеки України : наказ Міністерства економічного розвитку і торгівлі України від 29 жовтня 2013 р. № 1277. URL: http://cct.com.ua/ (дата звернення: 15.02.2020). 5. Дідур С. В., Глухова В. І., Скрипник Л. І. Аналіз та оцінка боргової безпеки України. Глобальні та національні проблеми економіки. 2016. № 13. С. 506-510. 6. Кучер Г. В. Ефективність системи управління державним боргом в Україні. Фінанси України. 2012. № 6. С. 4457. 7. Офіційний вебсайт Державного комітету статистики України. URL: http://www.ukrstat.gov.ua/ (дата звернення: 15.02.2020). 8. Офіційний вебсайт Міністерства фінансів України. URL: http://www.minfin.gov.ua/ (дата звернення: 15.02.2020). 9. Офіційний вебсайт Національного банку України. URL: http://www.bank.gov.ua/ (дата звернення: 15.02.2020). 10. Селіверстова I. 0. Боргова безпека як елемент фінансової безпеки держави. Проблеми системного підходу в економіці. 2010. № 3. URL: http://archive.nbuv.gov.ua/ (дата звернення: 10.02.2020).

\section{REFERENCES:}

1. Pro osnovy natsionalnoi bezpeky Ukrainy : Zakon Ukrainy vid 19.06.2003 № 964-IV (zi zminamy i dopovnenniamy). URL: http://zakon4.rada.gov.ua/ (data zvernennia: 15.02.2020). 2. Prohrama upravlinnia derzhavnym borhom na 2017 rik : nakaz MFU vid 31.01.17 № 19. URL: http://www.minfin.gov.ua (data zvernennia: 15.02.2020). 3. Pro zatverdzhennia Serednostrokovoi stratehii upravlinnia derzhavnym borhom na 20172019 roky : Postanova Kabinetu Ministriv Ukrainy vid 1 hrudnia 2017 r. № 905. URL: http://zakon5.rada.gov.ua/laws/ (data zvernennia: 15.02.2020). 4. Pro zatverdzhennia Metodyky rozrakhunku rivnia ekonomichnoi bezpeky Ukrainy : nakaz Ministerstva ekonomichnoho rozvytku i torhivli Ukrainy vid 29 zhovtnia 2013 r. № 1277 . URL: http://cct.com.ua/ (data zvernennia: 15.02.2020). 5. Didur S. V., Hlukhova V. I., Skrypnyk L. I. Analiz ta otsinka borhovoi bezpeky Ukrainy. Hlobalni ta natsionalni problemy ekonomiky. 2016. № 13. S. 506-510. 6. Kucher H. V. Efektyvnist systemy upravlinnia derzhavnym borhom v Ukraini. Finansy Ukrainy. 2012. № 6. S. 44-57. 7. Ofitsiinyi veb-sait Derzhavnoho komitetu statystyky Ukrainy. URL: http://www.ukrstat.gov.ua/ (data zvernennia: 15.02.2020). 8. Ofitsiinyi veb-sait Ministerstva finansiv Ukrainy. URL: http://www.minfin.gov.ua/ (data zvernennia: 15.02.2020). 9. Ofitsiinyi veb-sait Natsionalnoho banku Ukrainy. URL: http://www.bank.gov.ua/ (data zvernennia: 15.02.2020). 10. Seliverstova I. O. Borhova bezpeka yak element finansovoi bezpeky derzhavy. Problemy systemnoho pidkhodu $v$ ekonomitsi. 2010. № 3. URL: http://archive.nbuv.gov.ua/ (data zvernennia: 10.02.2020). 
Shylo Zh. S., Candidate of Economics (Ph.D.), Associate Professor (National University of Water and Environmental Engineering, Rivne)

\section{ANALYSIS AND EVALUATION OF DEBT SECURITY INDICATORS IN THE CONTEXT OF FINANCIAL AND ECONOMIC SECURITY MANAGEMENT}

The realities of Ukraine's debt policy show an increase in the debt of the state, both domestic and foreign. Significant debt dependency can endanger national security, including its financial security and debt security components. The purpose of this study is to unveil the theoretical and methodological foundations of forming and assessing the debt security of the state, to identify the main threats, to systematize and analyze their values for Ukraine in terms of approximation to the established critical limits, to develop possible recommendations for improving the system of debt security indicators and their critiques modern realities. In accordance with the stated goal, we outlined the following tasks: to study the theoretical and methodological principles of the level of assessment of the debt security of the state; to analyze the main debt security indicators of Ukraine; identify major threats and propose ways to improve Ukraine's debt security. Various indicators are used to assess the level of debt security: the World Bank, the International Monetary Fund, the Ministry of Economic Development and Trade of Ukraine, the author discloses the theoretical and methodological principles of the formation and assessment of debt security of Ukraine, its main threats and dangers, their systematic and analyzed values. In our view, debt instruments cannot be solved solely by debt policy instruments. It is necessary to carry out a set of measures aimed at reducing inflation, strengthening the national currency (hryvnia), optimizing the structure of budget expenditures on the principles of clear monetary constraints, optimizing sources and forms of financing public debt, channeling government borrowings to the real investment sector, stimulating domestic markets businesses through fiscal instruments. The state debt security level has been assessed and directions for improving public debt management and debt security optimization have been proposed. In general, public debt management and the optimization of debt security should become one of the key tasks of the state's economic policy, since reducing the debt of the state means reducing dependence on creditors, which in turn means increasing not only economic but also political independence of the state.

Keywords: debt security; financial and economic security management; debt security indicators; public and government guaranteed debt; average weighted yield of T-bills. 
Шило Ж. С., к.э.н., доцент

(Национальный университет водного хозяйства и природопользования,

г. Ровно)

\title{
АНАЛИЗ И ОЦЕНКА ПОКАЗАТЕЛЕЙ ДОЛГОВОЙ БЕЗОПАСНОСТИ ГОСУДАРСТВА В КОНТЕКСТЕ УПРАВЛЕНИЯ ФИНАНСОВО-ЭКОНОМИЧЕСКОЙ БЕЗОПАСНОСТЬЮ
}

\begin{abstract}
В научном исследовании проанализирован уровень долговой безопасности государства. Автором раскрыты теоретикометодологические основы формирования и оценивания долговой безопасности, выделены основные её угрозы и опасности, систематизированы и проанализированы их значения для Украины. Проведена оценка уровня долговой безопасности и предложены пути улучшения управления государственным долгом, а также оптимизация долговой безопасности.

Ключевые слова: долговая безопасность; управление финансовоэкономической безопасностью; индикаторы состояния долговой безопасности; государственный и гарантированный государством долг; средневзвешенная доходность ОВГЗ.
\end{abstract}

Стаття надійшла до редакції 24.03.2020 р. 